\title{
PENYULUHAN PENGELOLAAN KEUANGAN DAN MEMOTIVASI KARYAWAN PADA USAHA WEDDING ORGANIZER IWAN TENDA DEPOK DI MASA PENDEMI COVID-19
}

\author{
Siti Nurcahayati ${ }^{1}$, Nurul Ilham ${ }^{2}$, Anggada Bayu Seta $^{3}$, Roni Fadli ${ }^{4}$, Sri Mulyani ${ }^{5}$ \\ Universitas Pamulang \\ Email: dosen02356@unpam.ac.id
}

\begin{abstract}
Community Service Activities carried out by a team of lecturers in the undergraduate management study program at Pamulang University (UNPAM) in 2020 are community service activities that focus on simple financial management training for UMKM wedding organizer Iwan Tenda Depok. This activity begins with an explanation of how to manage finances properly and motivate employees, followed by training in making simple financial reports. The results obtained were 95\% of UMKM players were able to make simple financial reports independently. With this activity, it is hoped that it can be used as a solution to the problem of better financial management so that the benefits can be utilized as best as possible for the development of their business.
\end{abstract}

Keywords: Financial Training, Employee Motivation.

\begin{abstract}
Abstrak
Kegiatan Pengabdian Kepada Masyarakat yang dilakukan oleh tim dosen program studi manajemen S1 Universitas Pamulang (UNPAM) tahun 2020 merupakan kegiatan pengabdian kepada masyarakat yang menitik beratkan pada Pelatihan pengelolaan keuangan sederhana pada pelaku UMKM wedding organizer Iwan Tenda Depok. Kegiatan ini diawali dengan pemaparan bagaimana cara mengelola keuangan dengan baik dan memberi motivasi kepada karyawan dilanjutkan dengan pelatihan membuat laporan keuangan sederhana. Diperoleh hasil 95\% pelaku UMKM dapat membuat laporan keuangan sederhana secara mandiri. Dengan adanya kegiatan ini diharapkan dapat dijadikan solusi dalam masalah pengelolaan keuangan yang lebih baik agar keuntungan yang di dapat bisa dimanfaatkan sebaik mungkin untuk perkembangan usahanya.
\end{abstract}

Kata Kunci: Pelatihan Keuangan, Motivasi Karyawan.

\section{A. PENDAHULUAN}

Pandemi virus corona bukan hanya sekedar bencana kesehatan, virus yang dikenal sebagai covid-19 ini telah menimbulkan kekacauan di sektor ekonomi. Tidak hanya industri besar, pandemi virus Corona telah membuat pelaku UMKM di Indonesia mulai gelisah. Salah satu cara ampuh menekan penyebaran virus Corona ini adalah social distancing atau mudahnya jaga jarak. Anjuran-anjuran agar orang-orang tak berkerumun dan di rumah saja sudah sangat masif, baik yang dilakukan oleh lembaga resmi atau para relawan dan media. 
Pemerintah akan mengerahkan aparat untuk menegur siapa saja yang masih nekat menggelar acara yang mengundang keramaian. Kondisi tersebut, membuat sebagian orang kehilangan penghasilan sebab mereka mendapatkan uang dari pengumpulan massa. Salah satunya yang terkena imbasnya adalah pebisnis jasa penyelenggaraan acara pernikahan atau biasa disebut wedding organizer (WO).

Usaha Mikro Kecil dan Menengah atau UMKM merupakan bisnis yang juga memerlukan pengelolaan keuangan yang baik. Setiap bisnis akan membutuhkan pengelolaan keuanga yang tepat agar bisnis tetap bisa berjalan dengan lancar. Pengelolaan keuangan usaha penting untuk diterapkan pemilik UMKM. Menurut Ediraras (2010) bisnis UMKM yang keuangannya dikelola dan diinformasikan secara transparan dan akurat akan memberikan dampak positif terhadap bisnis UMKM itu sendiri. Jika hal ini dapat dilakukan oleh setiap wirausaha, maka besarlah harapan untuk dapat menjadikan usaha yang semula kecil menjadi skala menengah bahkan menjadi sebuah usaha besar.

Berdasarkan hasil observasi yang telah dilakukan, dalam menjalankan usahanya UMKM Iwan Tenda tidak luput dari adanya masalah-masalah eksternal baik dampak dari pemasalahan Covid-19 dan masalah yang bersifat internal yang menyebab penurunan omset dari usaha yang dilaksanakan oleh UMKM Iwan Tenda. Beberapa faktor yang ditemukan terkait permasalah yang dihadapi oleh usaha UMKM Iwan Tenda terkait manajemen keuangan adalah tidak adanya pencatatan keuangan secara berkala sehingga pendapatan masuk dan keluar tidak tercatat dengan baik, hal lain yang juga menjadi masalah adalah tidak adanya pencatatan patty cash (kas kecil) sehingga seringkali operasional harian usaha harus mengambil dari dana pribadi pemilik usaha. Sementara masalah terkait motivasi karyawan yang ada didalam UMKM Iwan Tenda antara lain, menurunnya semangat kerja karyawan karena adanya himbauan pelarangan berkerumun untuk acara pernikahan dan pesta, maslah berikutnya adalahhasil kerja yang masih kurang optimal, dan masalah lain juga kerap timbul adalah karyawan berkerja tidak sesuai dengan prosedur pekerjaan yang telah ditetapkan oleh pemilik usaha. Berdasarkan latar belakang dan permasalahan yang mitra hadapi yang telah diuraikan diatas, kami dari Tim Program Pengabdian Masyarakat (PKM) Universitas Pamulang (UNPAM) yang berjumlah 5 dosen terpanggil untuk ikut serta membantu memecahkan persoalan yang dihadapi oleh Iwan Tenda dengan judul PKM: "Penyuluhan Pengelolaan Keuangan dan Permotivasian Karyawan Pada Usaha Wedding Organizer di Masa Pandemi Covid-19".

\section{B. METODE PELAKSANAAN}

Kegiatan pengabdian kepada masyarakat ini dilakukan di Kelurahan Rangkal Panjaya Lama, Kecamatan Pancoran Mas Kota Depok. Dalam rangka mencapai tujuan yang tercantum di atas, maka pelaksanaan kegiatan pengabdian masyarakat ini dilaksanakan dengan beberapa metode, yaitu sebagai berikut:

1. Metode Ceramah

Peserta diberikan motivasi agar memiliki kemauan untuk menggunakan akuntansi dalam kegiatan bisnisnya. Selain itu, peserta diberikan materi tentang motivasi kerja dan pentingnya menjalankan prosedur kerja yang sudah ada.

2. Metode Tutorial dan Pelatihan

Peserta pelatihan diberikan materi akuntansi mulai dari pencatatan sampai dengan menyusun laporan keuangan. Dan pendalaman materi terkait standar operasional prosedur kerja UMKM Iwan Tenda. 
3. Metode Diskusi

Peserta pelatihan diberikan kesempatan untuk mendiskusikan permasalahan yang berkaitan dengan keuangan UMKM dan menurunnya semangat kerja yang selama ini dihadapi.

\section{HASIL DAN PEMBAHASAN}

Kegiatan pelatihan pengelolaan keuangan bagi UMKM di Kelurahan Rangkal Panjaya Lama, Kecamatan Pancoran Mas Kota Depok, dilakukan di area usaha Iwan Tenda Depok. Pelaku UMKM dan karyawan Iwan Tenda Depok yang menjadi target pelatihan, waktu pelaksanaan PKM serta tempat yang layak sebagaimana tertuang dalam dokumen rencana kegiatan.

Pelaksanaan pelatihan pada tanggal 10 November 2020, pertama diawali dengan registrasi dan pembukaan. Selanjutnya, dilanjutkan dengan pemberian materi dengan topik pengelolaan keuangan UMKM. Materi ini membahas pentingnya pengelolaan keuangan bagi UMKM. Materi kedua memberikan motivasi kerja dan pemaparan terkait visi dan misi usaha. Pemberian materi kepada peserta ini dimaksud agar peserta lebih mudah mengetahui dan memahami materi sehingga diharapkan dapat menjadi pedoman bagi peserta untuk mengajukan pertanyaan maupun diskusi yang proaktif pada saat kegiatan berlangsung.

Hasil dan luaran yang dicapai dalam pelaksanaan kegiatan pengabdian kepada masyarakat ini adalah sebagai berikut:

1. Meningkatnya pengetahuan dan pemahaman pelaku usaha tentang cara pembuatan laporan keuangan sederhana.

2. Keantusiasan peserta sangat terlihat jelas dimana hampir seluruh peserta aktif terlibat dalam proses kegiatan hingga selesai.

3. Evaluasi pada tingkat kesukaan konsumen (peserta) hampir semua peserta $>95 \%$ menyatakan suka dengan hasil kegiatan.

\section{KESIMPULAN DAN SARAN}

\section{Kesimpulan}

1. Pengetahuan dan pemahaman pelaku usaha dan karyawan wedding organizer Iwan Tenda Depok menjadi meningkat

2. Keterampilan pelaku usaha dalam pembuatan laporan keuangan semakin meningkat.

\section{Saran}

Mengingat besarnya manfaat kegiatan pengabdian pada masyarakat ini, maka selanjutnya perlu:

1. Mengadakan sosialisasi dan pelatihan serupa pada pelaku UMKM lain di Kecamatan yang lain, dengan materi yang sama.

2. Adanya kesinambungan program pasca kegiatan pengabdian ini sehingga pelaku usaha dan karyawannya benar-benar dapat mempraktekan keterampilan yang sudah di ajarkan.

\section{Ucapan Terima Kasih}

Rasa syukur dan suka cita kamu haturkan kepada segenap pihak yang telah mensukseskan kegiatan PKM dengan judul "Penyuluhan Pengelolaan Keuangan Dan Memotivasi Karyawan Pada Usaha Wedding Organizer Iwan Tenda Depok Di Masa Pendemi Covid-19" kepada:

1. Rektor Dr. H. Dayat Hidayat, M.M, Rektor Universitas Pamulang, Tangerang Selatan Banten. 
2. Dr. Ali Maddinsyah, S.E., M.M., selaku Ketua LPPM Universitas Pamulang, Tangerang Selatan - Banten.

3. Dr. Kasmad, S.E., M.,M., selaku Ketua Program Studi Manajemen S1 Universitas Pamulang, Tangerang Selatan - Banten.

4. Dr. Udin Ahidin, S.E., M.M., C.M.A, Selaku Wakil Program Studi Manajemen S1 Universitas Pamulang, Tangerang Selatan - Banten.

5. Drs. Waluyo Jati, M.M., Selaku Sekretaris Program Studi Manajemen S1 Universitas Pamulang Tangerang Selatan - Banten.

6. Mahasiswa Universitas Pamulang yang juga ikut berkontribusi terhadap kelancaran kegiatan PKM.

\section{DAFTAR PUSTAKA}

Dewi, I.K., Ahyani., Sudarso, A.P., Liawati., \& Widowati. (2020). PENGELOLAAN HASIL PERTANIAN DALAM MENINGKATKAN HARGA JUAL PADA PETANI DI DESA CICALENGKA KECAMATAN PAGEDANGAN KABUPATEN TANGERANG - BANTEN. DEDIKASI PKM. 1 (3).

Dumilah, R., Sunarto, A., Solihin, D., \& Maulida, H. (2020). Pelatihan Pemanfaatan Media Sosial Untuk Promosi Usaha Atau Bisnis Bagi Siswa. DEDIKASI PKM, 1(1), 26-33.

Ediraras, Dharma. (2010). Akuntansi dan Kinerja UMKM. Jurnal Ekonomi Bisnis Nomor 2, Volume 15.

Edy, Sutrisno. (2017). Manajemen Sumber Daya Manusia (Cetakan ke-9). Jakarta, Kencana.

Eugene F. Brigham and Joel F. Houston, (2012). Dasar-dasar Manajemen Keuangan (Terjemahan). Jakarta; Salemba Empat.

Fatwitawati, R., (2018), Pengelolaan Keuangan Bagi Usaha Mikro Kecil Menengah (UMKM) Di Kelurahan Airputih Kecamatan Tampan Kota Pekanbaru, SEMBADHA. Vol. 1 No.1.

Fadli, R. (2020). Pelatihan Manajemen Waktu dalam Mewujudkan Produktivitas Kerja pada Tenaga Kesehatan RSU Bhakti Asih, Jurnal Baktimas, 2 (2), 100-103.

Fadli, R. (2019). Pengaruh Kepemimpinan Terhadap Kinerja Karyawan PT. Tunas Perkasa Tekindo. Jurnal Semarak: Jurnal Ilmiah Prodi Manajemen Universitas Pamulang, 2 (2), 85-100.

Fadli, R. (2020). Pengaruh Motivasi Kerja Terhadap Kinerja Karyawan Pada Yayasan Bait Qur'ani Ciputat. Jurnal Jenius: Jurnal Ilmiah Prodi Manajemen Universitas Pamulang, $4(1), 70-79$.

Hasibuan, Malayu. (2017) Manajemen Sumber Daya Manusia Cetakan Kedua Puluh Satu. Jakarta, PT. Bumi Aksara.

Mardiana, S., Supriyatna, W., Hasanah, Y. M., Zakaria., \& Indirasari, I. (2010). Optimalisasi Anggaran Keuangan Di Masa Pandemi Pada Desa Cicalengka Kabupaten Pagedangan Tangerang. DEDIKASI PKM. 1 (3).

Qurbani, D., Mardiana, S., \& Nugroho, R. D. (2020). Meningkatkan Minat Dan Potensi Generasi Milenial Khususnya Siswa-Siswi SMK Darussalam Untuk Memulai Bisnis Online Dengan Sistem Dropship. DEDIKASI PKM. 1 (3). 
Sari, R., Suryani, N. L., Setiawan, R., Darmadi., \& Susanto, N. (2020). PENGELOLAAN SUMBER DAYA MANUSIA DALAM MENINGKATKAN PRODUKTIVITAS PADA UKM KELURAHAN PAGEDANGAN KABUPATEN TANGGERANGBANTEN. DEDIKASI PKM. 1 (3).

Solihin, D., Susanto, N., Setiawan, R., Ahyani, \& Darmadi. (2020). PENERAPAN STRATEGI PEMASARAN SEBAGAI UPAYA MENINGKATKAN USAHA KECIL DAN MENENGAH WARGA DI KELURAHAN PANINGGILAN UTARA CILEDUG. ABDI LAKSANA, 1(3), 351-355.

Solihin, D., Prasetiyani, D., Sari, A. R., Sugiarti, E., \& Sunardi, D. (2020). PEMANFAATAN BOTOL BEKAS SEBAGAI PENYARING AIR BERSIH SEDERHANA BAGI WARGA DESA CICALENGKA KECAMATAN PAGEDANGAN KABUPATEN TANGERANG. DEDIKASI PKM, 1(3), 98-102

Solihin, D. (2019), Pengaruh Current Ratio Dan Debt To Equity Ratio Terhadap Return On Asset (ROA) Pada PT Kalbe Farma, Tbk. KREATIF: Jurnal Ilmiah Prodi Manajemen Universitas Pamulang. 7 (1).

Widodo, S. E. (2015). Manajemen Pengembangan Sumber Daya Manusia, Yogyakarta: Pusaka Pelajar. 